\title{
TCERG1 L wt Allele
}

National Cancer Institute

\section{Source}

National Cancer Institute. TCERG1L wt Allele. NCI Thesaurus. Code C120564.

Human TCERG1 L wild-type allele is located in the vicinity of 10 q26.3 and is approximately $219 \mathrm{~kb}$ in length. This allele, which encodes transcription elong ation regulator 1-like protein, may be involved in insulin resistance. 